\title{
Café Scientifique: Nobel Laureate Communicates Science Across the World Carol Trager-Cowan
}

On the evening of Monday the 3rd of August 2009, the Victorian Bar of the Tron Theatre in Glasgow, Scotland, filled to bursting point to hear Nobel laureate Sir Harry Kroto talk on "Global Educational Outreach in the GooYouWiki-World." Sir Harry was talking at a joint event between Glasgow's Café Scientifique and the Royal Society of Chemistry. Sir Harry chose the title of his presentation to highlight the recent revolutionary impact of Google, YouTube, and Wikipedia on our ability to obtain information and therefore expand our knowledge and understanding of the world. Sir Harry sees the internet as a fantastic resource with which we can capture and make available to everyone the best and the most innovative teaching of the wonders of science.

Now Francis Eppes Professor of Chemistry and Biochemistry at Florida State University and Emeritus Professor at the University of Sussex, Professor Sir Harold Kroto was awarded the Nobel Prize for Chemistry (together with Robert Curl and Richard Smalley) in 1996 for the discovery of a new form of carbon, the $\mathrm{C}_{60}$, Buckminsterfullerene. He obtained a BSc degree in chemistry (1961) and a PhD degree in molecular spectroscopy (1964) at the University of Sheffield, U.K. In 1990 he was elected a Fellow of The Royal Society and in 1996 he was knighted for his contributions to chemistry. He was elected to the National Academy of Sciences in 2007.

Sir Harry spends a considerable amount of time contributing to numerous activities of benefit to science and society in general. For example, he was president of the Royal Society of Chemistry from 2002 to 2004; he has served on the board of the Scripps Institute Board of Scientific Governors since 2004; and he has provided evidence to policy bodies concerning the role and development of nanotechnology (e.g. "Nanoscience and Nanotechnologies: Opportunities and Uncertainties"). He devotes a substantial amount of time to communicating science to children; he travels all over the world to deliver his workshops to them.

With a strong belief in the power of the internet, Sir Harry has put massive effort into two global on-line initiatives. In 1994 he co-founded the Vega Science Trust to create "a broadcast platform for the science, technology, engineering and mathematics (STEM) communities, so enabling them to communicate on all aspects of their fields of expertise using exciting Internet opportunities....The Trust aims to provide well-informed views on tech-



nical issues, and so make science more accessible and understandable to the widest possible range of target audiences" (http://www.vega.org.uk/). In 2007, together with colleagues at Florida State University, he founded GEOSET (Global Educational Outreach for Science, Engineering and Technology), which "uses new technology to provide outstanding Science, Engineering and Technology (SET) teaching material. It is a highly flexible medium enabling a wide range of different educational approaches to be explored and it is particularly useful for SET teachers who will find valuable downloadable teaching resource material created by the best science and technology experts and educators. A key aim is to catalyze the creation of a global network of participating sites catering to the local and global need for much improved SET education" (http:/ / www.geoset.info/ and also see http:/ / geoset.fsu.edu/).

During the evening at Café Scientifique, Sir Harry provided the audience with a number of innovative examples from Vega and GEOSET. For example, on the Vega Web site he has brought together a wide range of videos including interviews with eminent scientists including a significant number of Nobel laureates. The Web site also offers discussions of "Issues of Concern," with videos on climate change, malaria, and politics. In the "Reflections on

INTERFACES seeks articles featuring the people and profession of materials. Send proposals to Bulletin@mrs.org.
Science" section (a collaboration with the U.K.'s Open University), viewers may watch videos on the physical properties of gases and how $\mathrm{x}$-rays cracked the structure of DNA. In collaboration with the British Broadcasting Corporation, there are "Science Career Videos" where young scientists talk about their work from environmental science to molecular gastronomy.

The Vega Web site also has videos and downloadable presentations on simple yet inventive activities such as putting together a Bucky world map where, in the process, the children learn the names of the continents of the world.

Sir Harry was also enthusiastic about the use of the video and the internet for the assessment of students. He gave as an example the presentation produced by Jennifer Goldsby on "recent research detailing the effects of inbreeding on animal populations and its impact on domestic animals" (http://geoset.fsu. edu/ugradprojects.html). Jennifer submitted her presentation for partial assessment for a class on ecology. Sir Harry was impressed by the quality of the work produced by the students and he also found watching the videos to be a much more enjoyable experience than marking exam scripts. Sir Harry predicts that in the future such presentations will form on-line CVs for students.

Unfortunately there was only time for Sir Harry to illustrate a small sample of the breadth of material made available by the Vega Science Trust and GEOSET. Sir Harry spent the majority of his presentation justifying the need for high quality science resources to combat the zeal with 
which creationist philosophies, for example, are expounded. Sir Harry passionately made the case for global science education based on scientific evidence. He abhors the creationist museums which claim, for example, that dinosaurs roamed the earth together with man and maintain that dinosaurs no longer exist because they died in Noah's flood; he is horrified that these museums are running children's education programs. Sir Harry is evangelical with regard to the negative impact of the extremes of religion on today's society. He sees the present level of ignorance about science, engineering, and technology as a recipe for disaster.

Sir Harry will hopefully be encouraged by initiatives such as Café Scientifique who was his host for his evening's presentation. The Café Scientifique is "a place where, for the price of a cup of coffee or a glass of wine, anyone can come to explore the latest ideas in science and technology" (www. cafescientifique.org/).

Hundreds of such cafés run all over the world; science is discussed in a friendly, informal and open environment in Argentina, Australia, Bangladesh, Belgium, Brazil, Bulgaria, Canada, Chile, Croatia, Denmark, Egypt, Finland, France, Germany, Greece, Hungary, India, Iran, Ireland, Israel, Italy, Japan, Kenya, Latvia, Lithuania, Macedonia, Mexico, The Netherlands, New Zealand, Norway, Pakistan, Philippines, Poland, Portugal, Romania, Russia, Serbia, South Korea, Spain, Sweden, Switzerland, Turkey, Uganda, the United Kingdom, and the United States.

Café Scientifique events are usually

\section{GooYouWiki-World Online Key}

Café Scientifique

www.cafescientifique.org

Glasgow's Café Scientifique www.cafescientifique.org/glasgow.htm

Café Sci movement in schools www.juniorcafesci.org.uk

Royal Society of Chemistry (RSC) www.rsc.org

Vega Science Trust

www.vega.org.uk

Global Educational Outreach for Science, Engineering and

Technology (GEOSET)

www.geoset.info

geoset.fsu.edu

www.geokri.org

"Nanoscience and Nanotechnologies: Opportunities and Uncertainties" www.nanotec.org.uk/report/

Nano\%20report\%202004\%20fin.pdf.

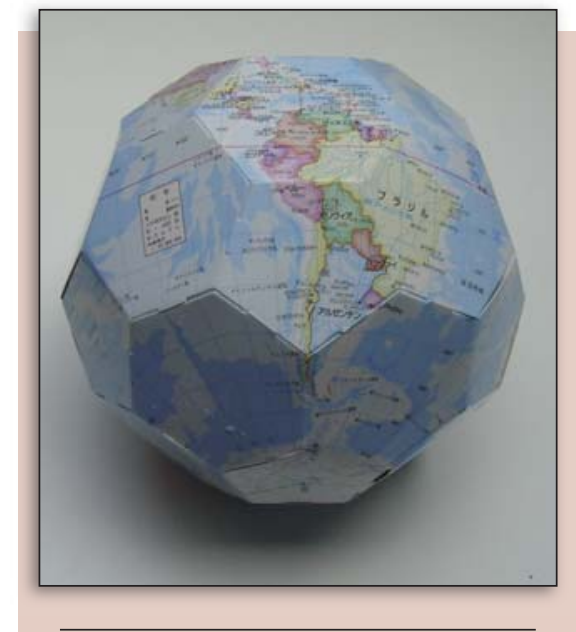

A hands-on activity devised by Sir Harry provides lessons about world geography in parallel with buckyballs!

held in informal venues such as cafés or bars. They start with a short 20-minute presentation where (in general) no PowerPoint slides are allowed-though an exception was made for Sir Harry due to the subject matter of his talk. Presentations are followed by a break to allow both the speaker and the audience to obtain refreshments. Once everyone's glass or coffee cup is refilled, the evening continues with animated discussion among the participants.

Topics discussed at Glasgow's Café Scientifique have included climate change; stem cells; the search for new worlds; superbugs, the quest for flight; heart disease; and bird song. The organizers of Glasgow's Café Scientifique, Mandy McLean (a professor at Glasgow University) and the broadcaster Vanessa Collingridge, actively encourage the audience to suggest future topics for discussion.

There is also a Café Sci movement in schools. A similar format is followed but, in this case, school pupils engage with scientists during their lunch break or after school in the informal environment of their school library or cafeteria. Topics debated have included, "Will men ever have babies?" to "Do boys and girls have the same IQ?" to "Are genetically modified crops doing more harm than good?" The school pupils provide their invited speakers with a considerable challenge, demanding answers to probing, insightful questions, which bodes well for the future of the inquiring mind and of the appreciation of evidence-based science. Let's hope such activities will give Sir Harry hope for the future.

Carol Trager-Cowan is a Reader in the Department of Physics at Strathclyde University, Glasgow, UK.

\section{JA I S}

Cryogenic Systems

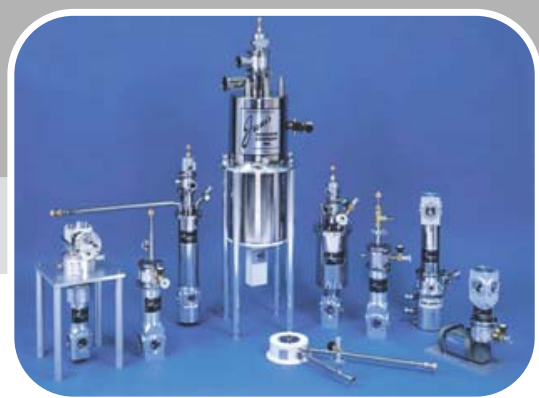

Does your research require low temperatures? Contact Janis today. Our engineers will assist you in choosing the best system for your application.

$10 \mathrm{mK}$ to $800 \mathrm{~K}$

- Cryocoolers

- LHe/LN $\mathrm{L}_{2}$ Cryostats
Magnet Systems

- Dilution Refrigerator Systems

Micro-manipulated Probe Stations 